\title{
PHOSPHORUS PROBLEM IN AGRICULTURE OF POLISSYA REGION AND WAYS OF ITS SOLUTION
}

\author{
${ }^{1}$ Hrynyk I. V., ${ }^{2}$ Berdnikov A. M., ${ }^{2}$ Potapenko L. V., ${ }^{2}$ Milyutenko T. B. \\ ${ }^{1}$ National Academy of Agrarian Sciences of Ukraine, \\ 38, Vasylkivska str, Kyiv, 03022, Ukraine \\ ${ }^{2}$ Institute of Agricultural Microbiology and Agroindustrial Production NAAS, \\ 97, Shevchenko str., Chernihiv, 14027, Ukraine \\ E-mail: isgm@ukrpost.ua
}

The paper covers the problem with phosphorus supply at crops cultivation on sod-podzolic soils of Polissya region. Issues of $\mathrm{P}_{2} \mathrm{O}_{5}$ renewal in the arable soil layer of sod-podzolic soils were reviewed together with the relationship between the phosphorus balance and crop rotation productivity, as well as role of biological preparation Polymyxobacteryn at periodic and additional application of technical phosphorus.

Keywords: phosphorus, biological preparation Polymyxobacteryn, fertilization system, soil phosphorus mode, crop rotation productivity.

In 2013 the grain production in the Chernihiv region, as well as in Ukraine, had reached its maximum, respectively, 3 and $60 \mathrm{mln}$. tons. What is important to understand is that grain formation is accompanied by high removal rates of phosphorus, while the realization of commodity grain - exclusion of significant amounts of phosphorous beyond the agrocenoses. Thus, 4 t/ha of winter wheat removes $45-50 \mathrm{~kg}$ of $\mathrm{P}_{2} \mathrm{O}_{5}$ from soil, $6 \mathrm{t} / \mathrm{ha}$ of corn $-70 \mathrm{~kg}$ of $\mathrm{P}_{2} \mathrm{O}_{5}, 4 \mathrm{t} / \mathrm{ha}$ of barley $55 \mathrm{~kg}, 2.5 \mathrm{t} / \mathrm{ha}$ of soybean $-40 \mathrm{~kg}, 25 \mathrm{t} / \mathrm{ha}$ of potatoes $-4 \mathrm{~kg}$ of $\mathrm{P}_{2} \mathrm{O}_{5}$.

However, the application rated of organic fertilizers in Chernihiv region and in the Polesye nowadays is not exceeding $2 \mathrm{t} / \mathrm{ha}$ and mineral $-70-90 \mathrm{~kg} / \mathrm{ha}$ of active ingredient, despite the fact that at such system the rate of nitrogen fertilizer is about $70-90 \%$. These fertilization approaches and level of crops productivity do not comply with the requirements of the classic agricultural chemistry - the law of the balance of nutrients, and phosphorus in particular $[1,2,3]$. Considering the fact that today we aim to nail down crop yields and preserve soil fertility, the search for optimization of phosphorus supply means becomes extremely important.

Through to 1990 in Chernihiv region and Polissya region in Ukraine the application of organic fertilizer was 10-12 t/ha, thus bringing to the soils $25-30 \mathrm{~kg} / \mathrm{ha}$ of available phosphorus and $170-180 \mathrm{~kg} / \mathrm{ha}$ of active NPK ingredients at 1:1:1 ratio, which taking into the account the crop yields had ensured a positive phosphorus balance at $30-40 \mathrm{~kg} / \mathrm{ha}$ at annual basis. Calculations indicate that in the last 10 years at the modern rate of crop productivity the phosphorus balance in Polissya region makes minus $30 \mathrm{~kg} / \mathrm{ha}$ or more each year. However, such situation with the phosphorus balance had not resulted in negative consequences in agriculture - a sharp 
decline of crops productivity. Why? It is believed that some methods of agrochemical research of soils, including the method for Kirsanov, do not always reflect the real content of the available phosphorus in the soil $[4,5,6]$. Undoubtedly, this is possible, but this can not explain no reduction in crop yields. Thus, there should be other explanations.

The performance analysis of the relationship of crop rotation and soil cultivation (Table 1) was conducted on the basis of the research data available [9]. It was shown that for yields up to $5 \mathrm{t} / \mathrm{ha}$ of grain units there is no direct correlation between the chemical composition of plants, soil cultivation level and their productivity, which indicates the presence of self-regulation mechanisms in the "soil plant" system. At the same time, at crop productivity on the level of $8.8 \mathrm{t} / \mathrm{ha}$ of grain units the changes in chemical composition of plants towards the increase of the content of basic nutrients, followed by the increase of removal rates of nitrogen - in 2.3 times, phosphorus - in 2 times, potassium - in 1.8 times.

\section{Table 1. Relationship between the crop rotation productivity and soil cultivation} (complex of agricultural suitability) and removal of the basic nutrients per yield or area units [9]

\begin{tabular}{|l|l|l|l|l|l|l|l|}
\hline \multirow{2}{*}{$\begin{array}{l}\text { Complex of } \\
\text { agricultural } \\
\text { suitability }\end{array}$} & \multirow{2}{*}{$\begin{array}{l}\text { Grain yield } \\
\text { units, } \mathrm{t} / \mathrm{ha}\end{array}$} & \multicolumn{4}{|l|}{$\begin{array}{l}\text { Nutrients uptake per } \\
\text { grain unit, } \mathrm{kg}\end{array}$} & \multicolumn{3}{l|}{$\begin{array}{l}\text { Nutrients removal, } \\
\mathrm{kg} / \mathrm{ha}\end{array}$} \\
\cline { 3 - 8 } & & $\mathrm{N}$ & $\mathrm{P}_{2} \mathrm{O}_{5}$ & $\mathrm{~K}_{2} \mathrm{O}$ & $\mathrm{N}$ & $\mathrm{P}_{2} \mathrm{O}_{5}$ & $\mathrm{~K}_{2} \mathrm{O}$ \\
\hline Wheat / Good & 8,8 & 2,60 & 1,08 & 2,96 & 230 & 96 & 262 \\
\hline Rye / Good & 4,9 & 2,23 & 0,99 & 2,87 & 110 & 49 & 142 \\
\hline Rye / Weak & 4,8 & 2,06 & 1,02 & 3,04 & 99 & 49 & 146 \\
\hline
\end{tabular}

System self-regulation can work only to a certain yield level (and, in our view for some time). Analysis of the research works of Ukrainian and foreign researchers $[2,7,8,9]$ indicates the importance for provision of necessary quantity of plant nutrients at their optimum ratio and in forms available to plants in any farming system. This is one of the basics for high crop yields and product quality. Besides, nutrients deficiency caused by their removal from with the yield, including phosphorus, cannot be systematically planned on poor soils (non-deficit or even negative balance of nutrients is allowed only on well-cultivated soils). In the future, the constant monitoring of soil nutrients availability should be performed; otherwise case a few years the negative balance of nutrients will inevitably lead to exhaustion and, therefore, reduction of crop yields. [9]

The results of our long-term field experiments on the medium cultivated sodpodzolic soils with high phosphorus content (by Kirsanov $160-180 \mathrm{mg} / \mathrm{kg}$ of soil), performed by factorial scheme with the dose of each nutrient (N, P, K) varied from 20 to $100 \mathrm{~kg}$ of active ingredient had shown that high yields above $8 \mathrm{t} / \mathrm{ha}$ of grain units can be achieved only under the positive balance of phosphorus on the level of $40 \mathrm{~kg}$, nitrogen $-30 \mathrm{~kg}$, potassium $-50 \mathrm{~kg} / \mathrm{ha}$ of active ingredients. 
Crop productivity on the level of $6 \mathrm{t} / \mathrm{ha}$ of grain units was received under the zero balance of phosphorus $\left(\mathrm{P}_{0}\right)$, positive $\left(+\mathrm{P}_{10}\right)$ and negative $\left(-\mathrm{R}_{10}\right)$ balances. It should be noted that for typical for Polissya zone crop rotation with perennial grasses under the stated crop productivity level the negative balance for nitrogen $\left(-\mathrm{N}_{20}\right)$ and potassium $\left(-\mathrm{K}_{30}\right)$ is possible.

At negative phosphorus balance $\left(-\mathrm{P}_{30}\right)$ already at fifth year the productivity of crop rotation had dropped to $4 \mathrm{t} / \mathrm{ha}$ of grain units, and was received at a higher deficit of nitrogen $\left(-\mathrm{N}_{50}\right)$ and potassium $\left(-\mathrm{K}_{60}\right)$. This emphasizes the primary role of phosphorus for plants productivity.

Taking into the account the foregoing, at modern conditions of soil fertilization with unilateral use of nitrogen fertilizer in $3-4$ years on medium and well-cultivated sod-podzolic soils of Polissya region a sharp decrease in yield, including cereals is forthcoming; on sandy and loamy sod-podzolic soils the negative results can be expected in 2-3 years while in some areas this phenomenon can be observed nowadays.

Getting back to the issue of relative self-regulation of "soil-plant" system it should be noted that the reasons of stable phosphorous content in the topsoil has no relevant explanations and are still under discussion. At our understanding the degree of phosphorus use by plants from the soil and fertilizers usually does not exceed 18\%; "residual" phosphorus from organic and mineral fertilizers orthogrades (fixed in the ground) and at its deficit plants are forced to use phosphorous reserves from the soil. This is ensured by soil acidification due to the use of nitrogen fertilizers, which without liming may cause the transition of hardly soluble phosphates in the mobile forms. From the D.M. Pryanishnikov works [7] it is known, that in nature there is a transformation mechanism of phosphorus from deeper layers of soil, where its sufficient reserves can be found. Moreover, they increase with depth $[10,11]$. Such specific biological "pump", which ensures the phosphorus supply from the lower horizons of the soil profile to the arable layer, is the root system of plants lupine plants (perhaps not only lupine). It also can be assumed that another reason of the increase of mobile phosphorous content in the topsoil is high excretory (soluble) function of plant roots of modern intensive varieties. Years ago only lupine, oats, buckwheat, rye were considered to as the intensive crops. Nowadays, soybeans, peas, vetch, corn and sunflower can be added to this list. Nevertheless, these data is not yet confirmed and should be studied more thoroughly.

Fertilizers application is well known replenishment of nutrients in the soil. However, modern German researchers [11] believe that there are other solutions to the problem, namely for vast amount of arable land the phosphorus content in the topsoil is $1400-10400 \mathrm{~kg} / \mathrm{h}$. Thus, these phosphorus can be used for decades or centuries. Moreover, the top layer $0-20 \mathrm{~cm}$ can not be considered as a system that may eventually exhaust, since it is dynamic. The availability of phosphorus to plants is largely depends on the condition and quality of the soil. As is was shown in series of our experiments, and other studies of phosphorous and potassium plant nutrition 
performed by K. Emanuel [11] there are no significant yield increases at unbalanced application of phosphate fertilizers and at the increase of their doses. It is noted that application of phosphorous fertilizers improves soil quality thus enhancing the availability of phosphorus to the plants.

So, in conventional, alternative and organic farming the optimization phosphorus nutrition is possible at upon creation of optimal conditions for plant growth and development - sufficient organic matter content, nitrogen, water, air and optimum thermal conditions, that can be achieved by insertion inclusion in the crop rotation grasses, legumes, using green manure plants.

Seeds inoculation with microbial preparations, that have phosphorous mobilizing microorganisms as their biological agents is of particular importance in optimization of soil nutrient mode and phosphorus in particular, especially in the initial phases of plant growth and development [12].

The advantages of microbial preparations use was shown in our studies conducted on middle cultivated sod-podzolic soils with a high phosphorus content $\left(160 \mathrm{mg} / \mathrm{kg} \mathrm{P}_{2} \mathrm{O}_{5}\right.$ by Kirsanov). The scheme of experiment had included different options with a balanced phosphorus supply, decreasing doses of technical phosphorus in the form of superphosphate at $\mathrm{P}_{25}$ under the use of microbial preparation Polymyxobacteryn.

Soil nutritional mode at the beginning of the growing season under the inoculation background without $\mathrm{P}_{25}$ had not changed as compared to the variants with full dose of phosphorous $\left(\mathrm{P}_{60}\right)$ (Table 2).

Table 2. Soil phosphorous mode under the corn crop, field experiment, $\mathrm{mg} / 100 \mathrm{~g}$

\begin{tabular}{|l|l|l|l|l|}
\hline \multirow{2}{*}{ Variants } & \multicolumn{3}{|l|}{ Plant growth stages } & Average for \\
\cline { 2 - 5 } & $6-8$ leaves & Flowering & Grain filling & vegetation \\
\hline Without fertilizers & 14,8 & 15,6 & 13,0 & 14,5 \\
\hline $\mathrm{N}_{90} \mathrm{P}_{60} \mathrm{~K}_{90}$ & 16,2 & 18,0 & 14,0 & 16,1 \\
\hline Green manure & 14,8 & 16,0 & 16,0 & 15,6 \\
\hline Manure & 14,8 & 16,0 & 16,0 & 15,6 \\
\hline $\begin{array}{l}\mathrm{N}_{90} \mathrm{P}_{35} \mathrm{~K}_{90}+ \\
\text { Polymyxobacteryn } \\
*\end{array}$ & 16,0 & 16,0 & 13,3 & 15,1 \\
\hline LSD $_{099}$ & 0,26 & 0,30 & 0,20 & \\
\hline
\end{tabular}

Note: * reduction of phosphorus dose on $25 \mathrm{~kg} / \mathrm{ha}$

On average, the content moving of $\mathrm{P}_{2} \mathrm{O}_{5}$ in soil during the vegetation period in variants with inoculation was higher relatively to control and equal to the indices in variants with organic fertilizer and green manure.

It should be noted, that at complete crop rotation: winter wheat-corn-oats-lupine the slight decrease of $\mathrm{P}_{2} \mathrm{O}_{5}$ content - on $20-15 \mathrm{mg} / \mathrm{kg}$ soil was observed in the control 
variant. Seeds inoculation with Polymyxobacteryn the increase of phosphorus content within the arable soil layer on $25-27 \mathrm{mg} / \mathrm{kg}$ as compared to its initial state was observed. In variants with green manure and organic fertilizer the content of mobile phosphorus in the topsoil had not increased while in the subsoil $(20-40 \mathrm{~cm})$ its number had increased on $22-24 \mathrm{mg} / \mathrm{kg}$ soil.

Combination of the reduced dose of phosphorous fertilizers with seeds inoculation with Polymyxobacteryn the crop yield in rotation and the output quality indices were equal to the variants with the complete dose of mineral fertilizers used (Table 3).

Polymyxobacteryn improves phosphorus nutrition of plants [12] by the intensive development of microorganisms in the root zone, while their metabolites dissolve mineral phosphates and induce the hydrolysis of organophosphates thus stimulate root development of plants. According to our observations, it also stimulates the productivity of photosynthesis on $10-14 \%$.

Polymyxobacteryn ensures more efficient use of phosphorous fertilizers applied beforehand. Thus, as it was established in field and lyzimiter studies using different fertilizer types - agrophos $\left(\mathrm{P}_{2} \mathrm{O}_{5}-19 \%\right)$ and ammophos $\left(\mathrm{P}_{2} \mathrm{O}_{5}-52 \%\right)$ within the complete fertilizer application: at continuous corn growing application of phosphorous at a dose of $\mathrm{P}_{150}$ once in three years was lower as compared to the annual use of fertilizers in dose $\mathrm{P}_{50}$ by $9 \%$. At seeds inoculation with Polymyxobacteryn there were almost no differences observes between the variants (Table 4, variant 2 and 4, background I and II), indicating the prospect of inoculation use at advance phosphorous use - once in three years when using low-cost phosphorous fertilizers in the form of natural phosphates enriched by magnetic separation means and suitable for organic farming.

Analysis of literature data and results of our studies had indicated the presence of self-regulation mechanisms of "soil-plant" system in terms of phosphorus supply. In four - five years this will ensure receipt a relatively high and stable crops, including cereals. However, at phosphorus balance deficit in farming the possible negative consequences of modern agricultural technologies that can occur (after the end of stabilizing the phosphorous regime) as a sharp decrease of crops productivity, including cereals should be prevented. Optimization of plants nutrition with phosphorus is possible by improving the agriculture techniques and increasing the soil fertility by growing legumes, use manure and intermediate green manure and presowing seeds inoculation with phosphorous mobilizing bacteria. On sod-podzolic soils with a high content of available phosphorus the seeds inoculation with microbial preparation Polymyxobacteryn is equivalent to the action of technical phosphorus at a dose $\mathrm{P}_{25}$. In order to obtain high and stable yields of grain and productivity of crop rotation on the level 7-8 t/ha of cereal production units in industrial scale the dose of technical phosphorus should be around $\mathrm{P}_{40-50}$, while at seeds inoculation this dose can be reduced by $20-30 \%$. 
Table 3. Crops yields at different fertilization systems and inoculation, t/ha

\begin{tabular}{|c|c|c|c|c|c|c|c|c|c|c|c|c|}
\hline \multirow[t]{2}{*}{ Variants } & \multicolumn{2}{|c|}{$\begin{array}{c}\text { Winter } \\
\text { wheat yield }\end{array}$} & \multirow{2}{*}{$\begin{array}{c} \pm \text { to } \\
\text { variant } \\
\text { w/o } \\
\text { inoculati } \\
\text { on }\end{array}$} & \multicolumn{2}{|c|}{$\begin{array}{c}\text { Corn (grain) } \\
\text { yield }\end{array}$} & \multirow{2}{*}{$\begin{array}{c} \pm \text { to } \\
\text { variant } \\
\mathrm{w} / \mathrm{o} \\
\text { inoculatio } \\
\mathrm{n}\end{array}$} & \multicolumn{2}{|c|}{$\begin{array}{l}\text { Naked oat } \\
\text { yield }\end{array}$} & \multirow{2}{*}{$\begin{array}{c} \pm \text { to } \\
\text { variant } \\
\text { w/o } \\
\text { inoculati } \\
\text { on }\end{array}$} & \multicolumn{2}{|c|}{$\begin{array}{c}\text { Blue lupine } \\
\text { yield }\end{array}$} & \multirow{2}{*}{$\begin{array}{c} \pm \text { to } \\
\text { variant } \\
\text { w/o } \\
\text { inoculati } \\
\text { on }\end{array}$} \\
\hline & $\mathrm{I}^{*}$ & $\mathrm{II}^{* *}$ & & $\mathrm{I}^{*}$ & $\mathrm{II}^{* *}$ & & $I^{*}$ & II $^{* *}$ & & $I^{*}$ & II $^{* *}$ & \\
\hline Control & 2,40 & 2,90 & $+0,50$ & 3,40 & 4,00 & $+0,60$ & 1,40 & 1,74 & $+0,34$ & 1,40 & 1,65 & $+0,25$ \\
\hline NPK & 4,06 & 4,07 & $+0,01$ & 6,61 & 6,60 & $-0,01$ & 2,06 & 2,04 & $-0,02$ & 1,42 & 1,70 & $+0,28$ \\
\hline $\begin{array}{l}\text { Green } \\
\text { manure - } \\
\text { blue lupine. }\end{array}$ & 4,00 & 4,64 & $+0,64$ & 5,60 & 6,20 & $+0,60$ & 1,81 & 1,91 & $+0,01$ & 1,60 & 2,00 & $+0,40$ \\
\hline $\begin{array}{l}\text { Green } \\
\text { manure }+ \\
\text { NPK }\end{array}$ & 4,72 & 4,96 & $+0,24$ & 8,20 & 8,06 & $-0,14$ & 3,02 & 3,08 & $+0,05$ & 1,60 & 2,08 & $+0,48$ \\
\hline $\begin{array}{l}\text { Manure, } \\
10 \text { t/ha }\end{array}$ & 4,14 & 4,50 & $+0,34$ & 5,01 & 5,40 & $+0,30$ & 2,40 & 2,70 & $+0,30$ & 1,90 & 2,20 & $+0,30$ \\
\hline $\begin{array}{l}\text { Manure + } \\
\text { NPK }\end{array}$ & 4,38 & 4,40 & $+0,02$ & 7,90 & 8,00 & $+0,10$ & 3,11 & 3,28 & $+0,17$ & 1,92 & 2,20 & $+0,28$ \\
\hline $\begin{array}{l}\text { Green } \\
\text { manure + } \\
\text { manure }+ \\
\text { NPK }\end{array}$ & 4,98 & 5,04 & $+0,06$ & 8,06 & 8,04 & $-0,02$ & 3,02 & 3,30 & $+0,28$ & 2,02 & 2,30 & $+0,28$ \\
\hline $\begin{array}{l}\text { Manure, } \\
20 \text { t/ha }\end{array}$ & 5,11 & 5,40 & $+0,29$ & 8,06 & 8,14 & $+0,08$ & 3,40 & 3,46 & $+0,06$ & 2,10 & 2,36 & $+0,26$ \\
\hline $\mathrm{LSD}_{0,95}$ & 0,22 & 0,24 & & 0,40 & 0,42 & & 0,12 & 0,14 & & 0,12 & 0,14 & \\
\hline
\end{tabular}

Note: I" - w/o inoculation; II ${ }^{* *}$ - seeds inoculation with Polymyxobacteryn of all crops in rotation at lower phosphorous

fertilizers dose $\left(-\mathrm{P}_{25}\right)$ 
Table 4. Efficiency of different fertilizers types and application means at continuous corn growing for grain

(average for 3 years)

\begin{tabular}{|c|c|c|c|c|c|c|c|c|c|c|c|}
\hline \multirow[t]{3}{*}{ \# } & \multirow[t]{3}{*}{ Variant } & \multicolumn{4}{|c|}{ Field experiment } & \multicolumn{6}{|c|}{ Lyzimeter experiment } \\
\hline & & \multicolumn{2}{|c|}{ Yield, t/ha } & \multicolumn{2}{|c|}{$\begin{array}{l}\text { Protein content } \\
\text { in grain }\end{array}$} & \multicolumn{2}{|c|}{ Yield, t/ha } & \multicolumn{2}{|c|}{$\begin{array}{l}\text { Protein content } \\
\text { in grain }\end{array}$} & \multicolumn{2}{|c|}{$\begin{array}{l}\mathrm{P}_{2} \mathrm{O}_{5} \text { losses from } \\
\text { leaching, } \mathrm{kg} / \mathrm{ha}\end{array}$} \\
\hline & & $I^{*}$ & $\mathrm{II}^{* *}$ & $\mathrm{I}$ & II & $\mathrm{I}$ & II & I & II & $\mathrm{I}$ & II \\
\hline 1 & $\begin{array}{l}\mathrm{N}_{120} \mathrm{P}_{50} \mathrm{~K}_{90}\left(\mathrm{P}_{50}\right. \\
\text { annually as } \\
\text { ammophos })\end{array}$ & 7,9 & 8,5 & 9,6 & 9,8 & 11,2 & 12,0 & 8,9 & 9,2 & 3,6 & 2,0 \\
\hline 2 & $\begin{array}{l}\mathrm{N}_{120} \mathrm{P}_{50} \mathrm{~K}_{90}\left(\mathrm{P}_{50}\right. \\
\text { as } \\
\text { nitroammophos })\end{array}$ & 8,2 & 8,6 & 10,2 & 10,2 & 10,2 & 12,2 & 10,0 & 10,2 & 3,6 & 1,2 \\
\hline 3 & $\begin{array}{l}\mathrm{N}_{120} \mathrm{P}_{50} \mathrm{~K}_{90}\left(\mathrm{P}_{50}\right. \\
\text { in advance for } 3 \\
\text { yeaars as } \\
\text { ammophos })\end{array}$ & 6,9 & 8,7 & 9,4 & 9,8 & 10,4 & 12,0 & 10,0 & 10,0 & 4,8 & 2,0 \\
\hline 4 & $\begin{array}{l}\mathrm{N}_{120} \mathrm{P}_{50} \mathrm{~K}_{90}\left(\mathrm{P}_{50}\right. \\
\text { in advance for } 3 \\
\text { years as } \\
\text { nitroammophos })\end{array}$ & 7,4 & 8,4 & 9,6 & 9,8 & 10,6 & 12,0 & 9,0 & 10,4 & 4,0 & 2,0 \\
\hline & $\mathrm{LSD}_{0,95}$ & 0,34 & 0,40 & & & 0,20 & 0,24 & & & & \\
\hline
\end{tabular}

Note: I $^{*}$ - w/o inoculation; II $^{* *}$ - seeds inoculation with Polymyxobacteryn 